\title{
Effect of Thaw Depth on Nitrogen and Phosphorus Loss in Runoff of Loess Slope
}

\author{
Feichao Wang ${ }^{1}$, Zhanbin $\mathrm{Li}^{1,2}$, Yuting Cheng ${ }^{3, *}$, Peng $\mathrm{Li}^{1}{ }^{1}$, Bin Wang ${ }^{1}$ and Hui Zhang ${ }^{4}$ \\ 1 State Key Laboratory of Eco-Hydraulics in Northwest Arid Region, Xi'an University of Technology, \\ Xi'an 710048, China; wangfeichao_0120@163.com (F.W.); zhanbinli@126.com (Z.L.); lipeng74@163.com (P.L.); \\ wenwu9264@163.com (B.W.) \\ 2 Key Laboratory of National Forestry Administration on Ecological Hydrology and Disaster Prevention in \\ Arid Regions, Xi'an University of Technology, Xi'an 710048, China \\ 3 College of Life Science, Yan'an University, Yan'an 716000, China \\ 4 China Jikan Research Institute of Engineering Investigations and Design Co., Ltd., Xi'an 710043, China; \\ zhanghui1017@yeah.net \\ * Correspondence: chengyutingstar@163.com; Tel./Fax: +86-29-8231-2658
}

check for updates

Citation: Wang, F.; Li, Z.; Cheng, Y.; Li, P.; Wang, B.; Zhang, H. Effect of Thaw Depth on Nitrogen and Phosphorus Loss in Runoff of Loess Slope. Sustainability 2022, 14, 1560. https://doi.org/10.3390/su14031560 Academic Editors: Sara Egemose and Luigi Aldieri

Received: 29 November 2021

Accepted: 20 January 2022

Published: 28 January 2022

Publisher's Note: MDPI stays neutral with regard to jurisdictional claims in published maps and institutional affiliations.

Copyright: (C) 2022 by the authors. Licensee MDPI, Basel, Switzerland. This article is an open access article distributed under the terms and conditions of the Creative Commons Attribution (CC BY) license (https:// creativecommons.org/licenses/by/ $4.0 /)$.

\begin{abstract}
Seasonal freeze-thaw erosion is a form of soil erosion caused by the topographical characteristics and climatic factors of the hilly and gully loess regions. Seasonal freeze-thaw can damage the soil pores and cause its bulk density to change. The effects of thawing depth on runoff and Nitrogen and Phosphorus loss on the rainfall erosion of an artificial slope filled with loess soil were analyzed after a rainfall test that simulated the spring thaw period in China. The results showed that: (1) The maximum runoff yield was $33.35 \mathrm{~mm}$ at $4 \mathrm{~cm}$ thawing depth, and the minimum was $12.95 \mathrm{~mm}$ at $6 \mathrm{~cm}$ thawing depth. With the increase in runoff time, the slope infiltration rate had a decreasing trend. The loss rate of available and total Phosphorus increased with the increase in runoff rate. The rate of increase was fastest when the thawing depth was $4 \mathrm{~cm}$. (2) The relationships between runoff rate and Nitrogen loss and Phosphorus loss rate can be explained by linear regression equations, and the loss rate increased as the runoff rate rose for all thawing depths. Within the $0-6 \mathrm{~cm}$ thawing depths, the loss of total phosphorus was the largest when the thawing depth was $4 \mathrm{~cm}$, and the loss of available phosphorus was the smallest when the thawing depth was $6 \mathrm{~cm}$. At the shallower thawing depths, the available Nitrogen loss represented a smaller proportion of the total Nitrogen loss compared to nitrate Nitrogen loss. However, there was a gradual rise in the available Nitrogen proportion in the total amount of inorganic Nitrogen as the thawing depth increased. (3) Total Phosphorus was the available Phosphorus with a quadratic function relationship with runoff energy and runoff power. Runoff energy mainly affected the total Nitrogen and available Nitrogen loss in runoff, whereas runoff power mainly affected total Nitrogen loss in runoff. The results of this paper can improve the understanding of runoff and Nitrogen and Phosphorus loss caused by runoff during freeze-thaw conditions.
\end{abstract}

Keywords: thawing depth; nitrogen and phosphorus loss; runoff energy; runoff power

\section{Introduction}

Soil played a major role in global N (Nitrogen) and P (Phosphorus) cycles because they are much larger reservoirs of organic $\mathrm{N}$ and $\mathrm{P}$ than terrestrial plants. The seasonal freeze-thaw process, which influences soil nitrification, organic carbon mineralization, and dissolved organic acids, affects the migration and transformation direction of Nitrogen and Phosphorus, and morphological changes by changing the physical and chemical properties and biological characteristics of soil [1-3].

During the spring thawing period, as the temperature rises, the surface soil begins to thaw, whereas the lower soil layer soil remains frozen and forms an impermeable layer. Rainfall and snowmelt cannot infiltrate the permafrost soil, which results in surface runoff 
that causes serious soil erosion [4]. The incompletely thawed layer means that soil erosion during the spring thaw period accounts for the vast majority of soil erosion throughout the year [5]. Soil thawing depth is one of the main factors affecting soil erosion during spring thawing. It also significantly affects the development of sheet erosion and rill erosion [5,6]. The smaller the soil thawing depth, the greater the snowmelt runoff erosion rate during the early stage of the spring thaw period [6,7]. Freezing and thawing causes a series of changes in the soil, such as soil aggregates destruction, soil moisture redistribution, soil microbial death, and accelerated plant root death due to reduced nutrient absorption [8-13]. As the depth of thawing increases, Nitrogen leaching rises, and ammonium Nitrogen in the organic and inorganic colloids, which was previously unusable in the soil, is released and is eventually lost due to runoff. Therefore, changes in thawing depth during the freeze-thaw process have potential impacts on soil Nitrogen availability and soil ecosystem productivity [14].

Fan et al. [15] found that the amount of Phosphorus adsorbed by soil decreased with increasing concentrations of exogenous Phosphorus under repeated freeze-thaw conditions. This was the result of damage to the soil structure caused by freeze-thawing, the change of particle size and stability of soil aggregates and the increase in specific surface area of soil, which provided more sites for Phosphorus adsorption [16]. At the same time, this process caused other types of ions to be released into the soil solution, which then competed with phosphate for the adsorption points on the soil particles [5]. As a result, the original adsorbed phosphate on the surface of the soil particles was replaced, and the soil became Phosphorus resistant, demonstrated by a weakening of the adsorption capacity [17]. Dagesse et al. [18,19] found that freeze-thaw changes the direction of soil water transport, content, aggregate structure and soil stability, which directly leads to changes in the physical and chemical properties and microbial activity of soil, producing soil that contains plant nutrients. The elemental biogeochemical cycle and the reaction rate change $[20,21]$. The freeze-thaw cycle also promotes the conversion of moderately active organic Phosphorus to moderately stable organic Phosphorus, accelerates the release of Phosphorus from soil aggregates and dead microbial residues, and weakens the desorption capacity of Phosphorus [22]. It also leads to the decrease in soil particle size and a change of iron-aluminum compound morphology, which further affects the adsorption behavior of Phosphorus in frozen soil [15]. The mutual conversion between soil water solid and liquid phase changes the Phosphorus content in aqueous solution, while the water content is closely related to the deposition and release of Phosphorus in soil [23]. Periodic freezethaw changes the supply of organic Phosphorus to dead soil microorganisms and plant residues [24]. Therefore, the freeze-thaw of soil changes, for example, the structure of soil aggregates, water stability, porosity, bulk density, water content, and specific surface area, resulting in poorer soil stability and erosion [7,25-29].

The Loess Plateau is in a temperate continental monsoon climate zone, with a temperature below $0{ }^{\circ} \mathrm{C}$ between 105 and 125 days. The soil in this area is mainly yellow loess soil, and its unique mineral composition and chemical composition mean that loess soil has a smaller specific heat value and there are large changes in soil temperature [30]. In recent years, with the implementation of the national ecological civilization strategy, which aims to control soil erosion, soil nutrient loss has become an important research area for the agriculture and environmental sectors. Existing governance patterns did not fundamentally change the basic water environment situation due to a lack of understanding about soil erosion and nutrient relationships, especially in a freeze-thaw environment. The relationship between soil erosion and nutrient loss is still unclear.

This paper used the loess soil of the Loess Plateau as the research object and analyzed the runoff-sediment-Nitrogen/Phosphorus loss characteristics and their relationships under different thawing depths by undertaking a simulated rainfall test. The effects of thawing depth and hydraulic erosion on Nitrogen and Phosphorus migration were studied. In addition, we analyzed the runoff power and runoff energy on $\mathrm{N}$ and $\mathrm{P}$ loss. The aim of this 
paper was to provide a theoretical basis for the optimal management of water resources and agricultural fertilization during the spring thawing period on the Loess Plateau.

\section{Materials and Methods}

\subsection{Soil and Soil Flume Preparation}

The test soil was collected from Suide county, Shaanxi Province, China. The soil type was the loessal soil, which is one of the soil types in Loess Plateau area. After the soil had been dried, it was filtered through a sieve with $10 \mathrm{~mm}$ diameter holes, and the plant roots, stones, and other debris were removed. The physical and chemical properties of selected soil are shown in Table 1.

Table 1. Physical and chemical properties of the selected soil.

\begin{tabular}{|c|c|c|c|c|c|c|c|c|c|}
\hline \multirow{2}{*}{$\begin{array}{l}\text { Soil } \\
\text { Type }\end{array}$} & \multicolumn{3}{|c|}{ Soil Particle/mm } & \multirow{2}{*}{$\begin{array}{c}\text { Bulk } \\
\text { Density }\end{array}$} & \multirow{2}{*}{$\begin{array}{c}\begin{array}{c}\text { Total } \\
\text { Nitrogen } \\
(\mathrm{TN})\end{array} \\
\left(\mathrm{g} \cdot \mathrm{kg}^{-1}\right)\end{array}$} & \multirow{2}{*}{$\begin{array}{c}\begin{array}{c}\text { Total } \\
\text { Phosphorus } \\
\text { (TP) }\end{array} \\
\left(\mathrm{g} \cdot \mathrm{kg}^{-1}\right)\end{array}$} & \multirow{2}{*}{$\begin{array}{c}\begin{array}{c}\text { Available } \\
\text { Phosphorus } \\
\text { (AP) }\end{array} \\
\left(\mathrm{g} \cdot \mathbf{k g}^{-1}\right)\end{array}$} & \multirow{2}{*}{$\begin{array}{c}\begin{array}{c}\text { Ammonia } \\
\text { Nitrogen } \\
(\mathrm{AN})\end{array} \\
\left(\mathrm{mg} \cdot \mathrm{kg}^{-1}\right)\end{array}$} & \multirow{2}{*}{$\begin{array}{c}\begin{array}{c}\text { Nitrate } \\
\text { Nitrogen } \\
(\mathrm{NN})\end{array} \\
\left(\mathrm{mg} \cdot \mathrm{kg}^{-1}\right)\end{array}$} \\
\hline & $\begin{array}{c}\text { Clay } \\
<0.002\end{array}$ & $\begin{array}{c}\text { Silt } \\
0.002 \sim 0.02\end{array}$ & $\begin{array}{c}\text { Sand } \\
0.02 \sim 2.0\end{array}$ & & & & & & \\
\hline Loess & 0.20 & 65.20 & 34.60 & 1.29 & 0.74 & 0.56 & 6.07 & 5.36 & 3.21 \\
\hline
\end{tabular}

The simulated rainfall test used a wooden soil bin that was $2 \mathrm{~m}$ long, $0.75 \mathrm{~m}$ wide, and $0.30 \mathrm{~m}$ high. The wood was $3 \mathrm{~cm}$ thick, which meant that the soil could be kept warm and that a one-dimensional thaw occurred in the vertical direction of the soil. The lower end of the soil bin was connected to a collecting tank, which was used to collect runoff and sediment samples. The rainfall experimental equipment was designed by the $\mathrm{Xi}^{\prime}$ an University of Technology Institute for Water Resources [31]. Effective rainfall area was $4.5 \mathrm{~m} \times 4.5 \mathrm{~m}$, rainfall height was $5.2 \mathrm{~m}$, and rainfall evenness was $\geq 85 \%$. (Figure 1 ).
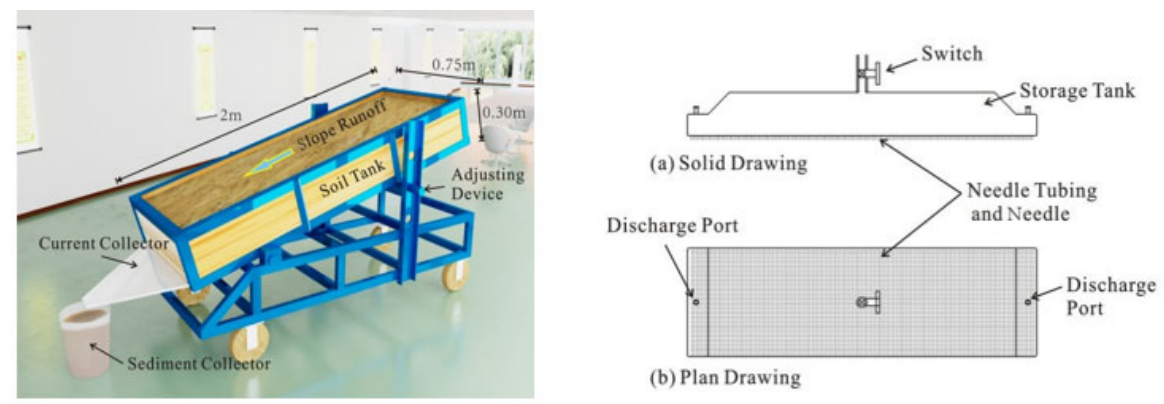

Figure 1. Schematic diagram of the soil tank test and needle tube assembly moving device for simulating rainfall.

The permafrost system was designed by the Xi'an University of Technology. The container size was $4.5 \mathrm{~m}$ long, $2.5 \mathrm{~m}$ wide, and $2.5 \mathrm{~m}$ high (Figure 2). The temperature range was from -40 to $30^{\circ} \mathrm{C}\left( \pm 1^{\circ} \mathrm{C}\right)$ The temperature uniformity was $\leq \pm 2{ }^{\circ} \mathrm{C}$. 


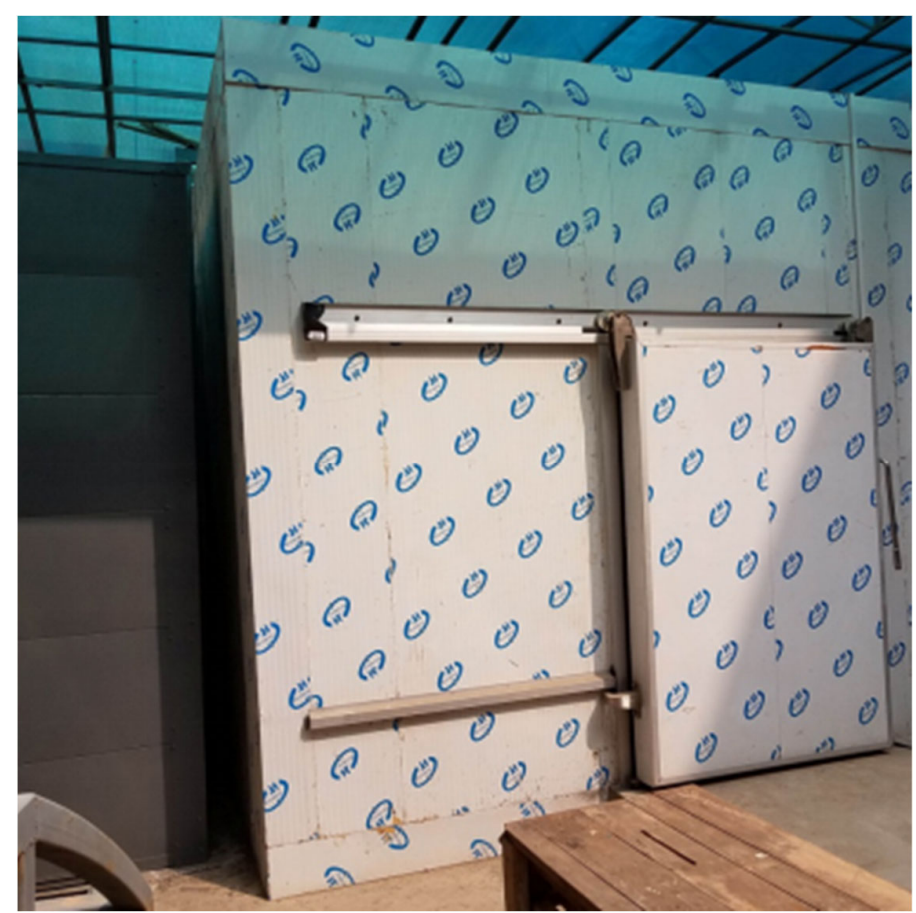

Figure 2. The permafrost system.

\subsection{Experimental Design and Methods}

There were four thaw depths $(0,2,4$, and $6 \mathrm{~cm})$. The initial soil water content was set at $15 \%$, the slope gradient was set at $15^{\circ}$; and the rainfall intensity was set at $0.9 \mathrm{~mm} \mathrm{~min}^{-1}$, which were all based on the loess soil moisture levels on the initial measurement date and the rainfall data. The experimental design is shown in Table 2.

Table 2. Statistical results for runoff analysis at the different thawing depths.

\begin{tabular}{cccc}
\hline Thawing Depth/cm & Runoff Time/min & Drop Pit Time/min & Runoff Yield/mm \\
\hline 0 & 5.47 & 10.38 & 24.41 \\
2 & 12.83 & 7.50 & 32.84 \\
4 & 16.44 & 7.00 & 33.35 \\
6 & 31.38 & 11.00 & 12.95 \\
\hline
\end{tabular}

A layer of gauze was then placed across the bottom of the soil flumes and embedded in $2 \mathrm{~cm}$ thick natural sand in order to ensure that permeability was close to that of natural slopes and to ensure uniform soil moisture infiltration. Then, the prepared soil materials were added to the bin. The consistency of the test slope soil physical properties was controlled by adding $5 \mathrm{~cm}$ thick layered fill soil material that was interlayered with a rough cast contact area. This layering also prevented the appearance of stratification and ensured a uniform soil. The bulk density was controlled at about $1.3 \mathrm{~g} / \mathrm{cm}^{-3}$. This was based on Equation (1), which was used to calculate the required soil weight:

$$
m=B \times(1+w) \times l \times b \times h
$$

where $m$ is the required soil weight, $\mathrm{kg} ; B$ is dry density, $1.3 \mathrm{~g} / \mathrm{cm}^{-3} ; w$ is water content, $15 \%$; and $l, b$, and $h$ are the soil bin length, width, and height, respectively.

After adding the soil, the soil bin was moved into the permafrost system and frozen for more than $24 \mathrm{~h}$ at temperatures that were between -18 and $-22{ }^{\circ} \mathrm{C}$, which ensured that the soil was completely frozen. The soil bin was then removed from the permafrost system and left to thaw until the thawed layer reached the design thaw depth. The thaw depth was measured using steel needle method [32]. The water temperature was kept at 
around $15{ }^{\circ} \mathrm{C}$ during the rainfall period, and the runoff period lasted $60 \mathrm{~min}$. When the slope outlet started to flow, a plastic bucket was used to collect the runoff samples from the water outlet every $5 \mathrm{~min}$. The samples were left to stand for $24 \mathrm{~h}$. Then, the supernatants were removed and stored at $4{ }^{\circ} \mathrm{C}$. The remaining samples were filtered and weighed after air-drying to calculate the sediment yield and flow rate. The concentration of Nitrogen and Phosphorus in the runoff was measured with an intermittent chemical analyzer Clever Chem200+ (Dechem-Tech. GmbH, Hamburg, Germany).

\subsection{Data Analysis}

Sheet flow plays an important role in the stripping and suspension of soil particles. Runoff energy $(E)$ is the work performed by the sheet flow in a unit area per unit time and represents the ability of runoff to achieve soil denudation and migration. Storms lasting for a short period of time are the major type of rain on the Loess Plateau. They cause serious soil erosion where the runoff mechanism is super-infiltration flow. Assuming that the rainfall is uniform, the water depth $h$ at any point on the slope is: $h=I-f$, where $I$ is rainfall intensity at any time, and $f$ is the infiltration rate at the corresponding time, assuming that the slope width is $B, \mathrm{~m}$; the slope gradient is $\theta,{ }^{\circ}$; and the slope length is $L$, $\mathrm{m}$. When equally dividing the slope, $\Delta x$ is the slope length per unit, and the water depth of the step is $i$. Then, $h_{i}=h \cos \theta$, such that:

$$
d E_{\text {runoff }}=\operatorname{dv\rho gx\operatorname {sin}\theta }
$$

where $d E_{\text {runoff }}$ is the potential energy of runoff; $d v$ is the runoff volume, such that $d v=$ $B h_{i} d x ; g$ is the gravitational acceleration, $\mathrm{m} \cdot \mathrm{s}^{-2}$; and $x$ is the distance between the runoff and the slope bottom, m. Integrating Equation (3)

$$
E_{\text {runoff }}=\frac{\rho g}{2} B L^{2} h_{i} \sin \theta
$$

shows that runoff energy throughout the rainfall, $E_{\text {runoff }}^{\prime}$, is equal to the integral of $E_{\text {runoff }}$ with respect to time:

$$
E_{\text {runoff }}^{\prime}=\int_{0}^{t} E_{\text {runoff }} d t
$$

Adding $h_{i}=h \cos \theta=(I-f) \cos \theta$ into Equations (5) and (6) gives

$$
E_{\text {runoff }}^{\prime}=\frac{\rho g}{4} B L^{2} \sin 2 \theta \int_{0}^{t}(I-f) d t=\frac{\rho g}{4} B L^{2} q_{h} \sin 2 \theta
$$

where $q_{h}=\int_{0}^{t}(1-f) d t$ is net rainfall, mm. Equation (5) can be written as the average runoff energy per unit area:

$$
E_{\text {runoff }, A}=E_{\text {runoff }}^{\prime} /(B L)=\frac{\rho g}{4} L \sin 2 \theta q_{h}
$$

where $E_{\text {runoff }, A}$ is the average runoff energy per unit area, $\mathrm{J}, \mathrm{m}^{-2}$.

In this paper, a previously proposed method [33] was used to calculate runoff power as follows:

$$
\begin{aligned}
& P=Q^{\prime} H \\
& Q^{\prime}=\frac{Q}{S}
\end{aligned}
$$

where $P$ is runoff power, $\mathrm{L}^{4} \cdot \mathrm{s}^{-1} \cdot \mathrm{m}^{-2} ; Q^{\prime}$ is the peak flow modulus, $\mathrm{L} \cdot \mathrm{s}^{-1} \cdot \mathrm{m}^{-2} ; H$ is water depth, $\mathrm{m} ; Q$ is the peak flow, $\mathrm{m}^{3} \cdot \mathrm{s}^{-1}$; and $S$ is the slope area, $\mathrm{m}^{2}$. 


\section{Results and Discussion}

\subsection{Effect of Thawing Depth on Runoff}

The statistical analysis of runoff for the different thawing depths is shown in Table 2. Table 2 shows that when the thawing depth was 0 and $6 \mathrm{~cm}$, the time at which water appeared in the drop pit (drop pit time) was later than the 2 and $4 \mathrm{~cm}$ thawing depths. During the spring thawing period, the frozen soil layer prevents infiltration. This causes the runoff time to advance, which affects runoff. Therefore, soil thawing depth had significant effects on runoff on the slope. When the thawing depth was 2 and $4 \mathrm{~cm}$, runoff $a$ was greater than when the thawing depths were 0 and $6 \mathrm{~cm}$.

The relationship between thawing depth and runoff time and runoff were explored, and the results are shown in Figure 3. The results showed that relationship between thawing depth and runoff time was exponential:

$$
t=6.0554 e^{0.2744 h} \mathrm{R}^{2}=0.9611
$$

and the thawing depth was related to runoff by nonlinear functions:

$$
q_{r}=-1.8019 h^{2}+9.1177 h+23.76 \mathrm{R}^{2}=0.9692
$$

where $t$ is runoff time, $\mathrm{min} ; h$ is thawing depth, $\mathrm{cm}$; and $q_{r}$ is runoff, $\mathrm{mm}$.
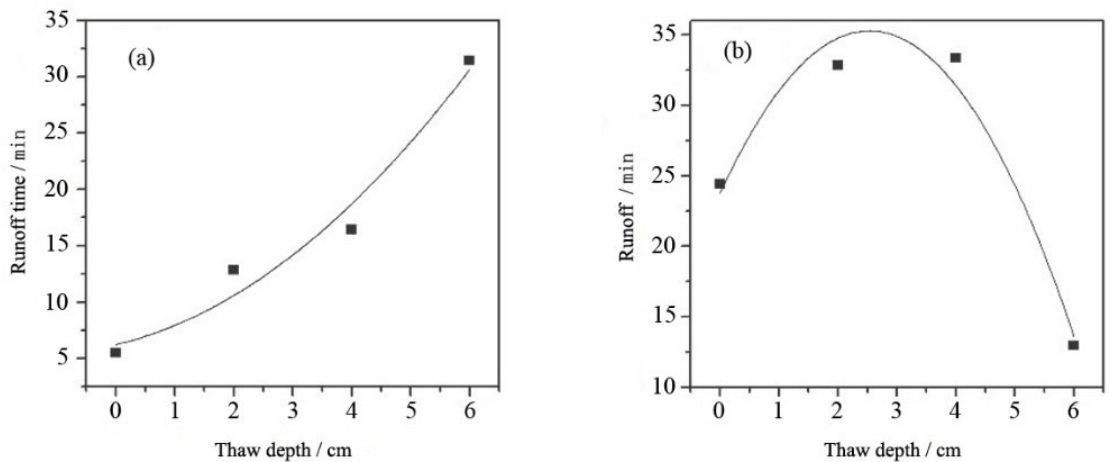

Figure 3. Relationships between the different thawing depths and runoff time (a) and runoff (b).

Runoff first increased and then decreased as the thawing depth increased, which showed that a critical value exists for thawing depth and that it affects runoff under laboratory conditions.

The relationships between thaw depth and runoff time and runoff in the Figure 3, the thawing depth increases with the increase in runoff time, and the runoff first increases and then decreases with the increase in thawing depth. The runoff loss rate for the different thawing depths are shown in Figure 4. The initial runoff loss rate was largest when the thawing depth was $2 \mathrm{~cm}$ and increased rapidly as the runoff time rose. When the thawing depth is $4 \mathrm{~cm}$, the runoff loss rate has little difference with $2 \mathrm{~cm}$. When the melting depth is $0 \mathrm{~cm}$, the difference of runoff loss rate between the first $20 \mathrm{~min}$ and $4 \mathrm{~cm}$ is small, and the runoff loss rate fluctuates between 0.3 and $0.5 \mathrm{~L} /\left(\mathrm{m}^{2} \cdot \mathrm{min}\right)$ after $20 \mathrm{~min}$. The runoff loss rate was smallest when the thawing depth was $6 \mathrm{~cm}$ and increased slowly at this depth as the runoff time rose. 


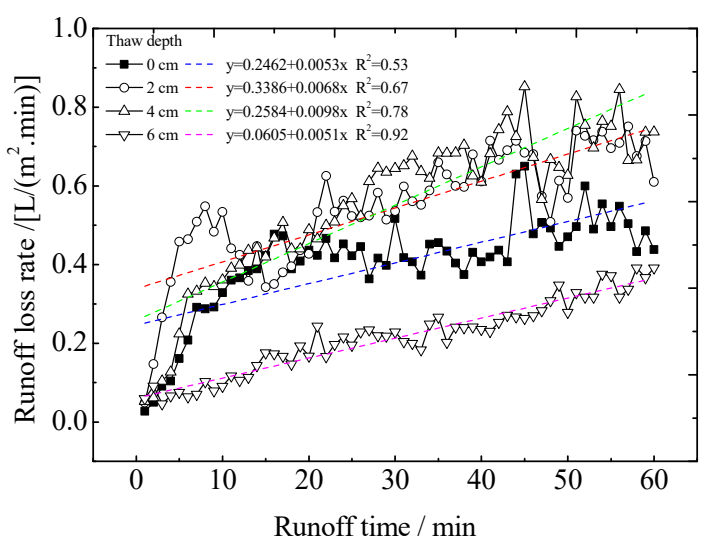

Figure 4. Runoff loss and sediment yield rates of the different thawing depths.

\subsection{Nitrogen and Phosphorus Loss Due to Runoff}

There was a positive correlation between runoff rate and nitrogen loss for different melting depths (Figure 5 and Table 3.). The results of residual analysis are shown in Figure 6, which shows that the model can be used to describe the relationship between runoff loss rate and nitrogen loss. The correlations between runoff rate and TN, AN, and NN loss rate were significant, and these relationships can be described by the linear equations. The $\mathrm{T}$ test showed that there was a significant difference between the slope of the regression equations at the different thawing depths for the $\mathrm{AN}, \mathrm{NN}$, and TN loss rate $(p<0.05)$, which indicated that the runoff loss rate at the different thawing depths had different effects on Nitrogen loss. This showed that the runoff loss rate and thawing depth had different effects on Nitrogen loss in runoff.
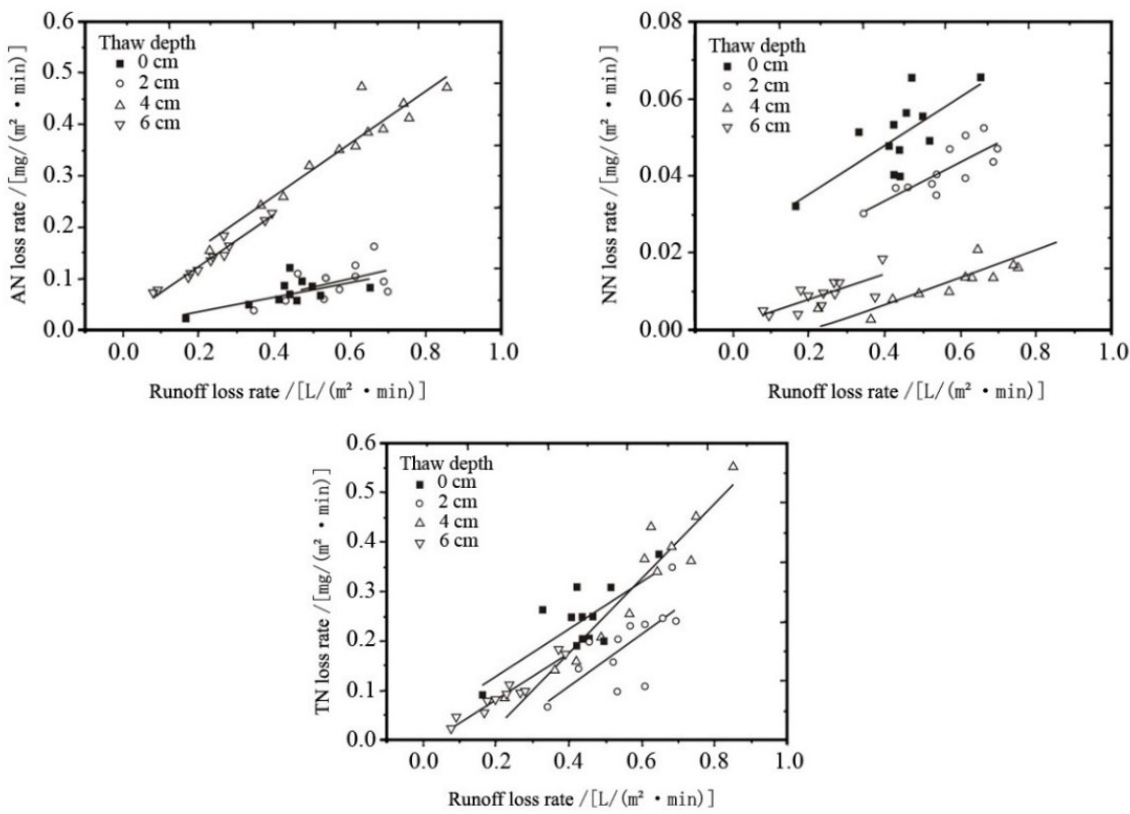

Figure 5. Relationship between runoff rate and Nitrogen loss rate of the different thawing depths. 
Table 3. Regression equations of the runoff loss rate and Nitrogen loss rate.

\begin{tabular}{|c|c|c|c|c|c|c|}
\hline \multirow{2}{*}{$\begin{array}{c}\text { Thaw } \\
\text { Depth/cm }\end{array}$} & \multicolumn{2}{|c|}{ Total Nitrogen } & \multicolumn{2}{|c|}{ Ammonium Nitrogen } & \multicolumn{2}{|c|}{ Nitrate Nitrogen } \\
\hline & $\begin{array}{l}\text { Regression } \\
\text { Equation }\end{array}$ & $\mathbf{R}^{2}$ & $\begin{array}{l}\text { Regression } \\
\text { Equation }\end{array}$ & $\mathbf{R}^{2}$ & $\begin{array}{c}\text { Regression } \\
\text { Equation }\end{array}$ & $\mathbf{R}^{2}$ \\
\hline 0 & $y=11.8849 x+0.867$ & 0.54 & $y=0.1348 x+0.0144$ & 0.62 & $y=0.0629 x+0.0232$ & 0.72 \\
\hline 2 & $y=13.1681 x-2.57$ & 0.46 & $y=0.1757 x-0.0034$ & 0.57 & $y=0.0503 x+0.0138$ & 0.80 \\
\hline 4 & $y=18.8339 x-3.13$ & 0.89 & $y=0.5096 x+0.0608$ & 0.94 & $y=0.0353 x-0.0068$ & 0.86 \\
\hline 6 & $y=11.6143 x-0.28$ & 0.91 & $y=0.4987 x+0.0284$ & 0.98 & $y=0.0329 x+0.0018$ & 0.75 \\
\hline
\end{tabular}
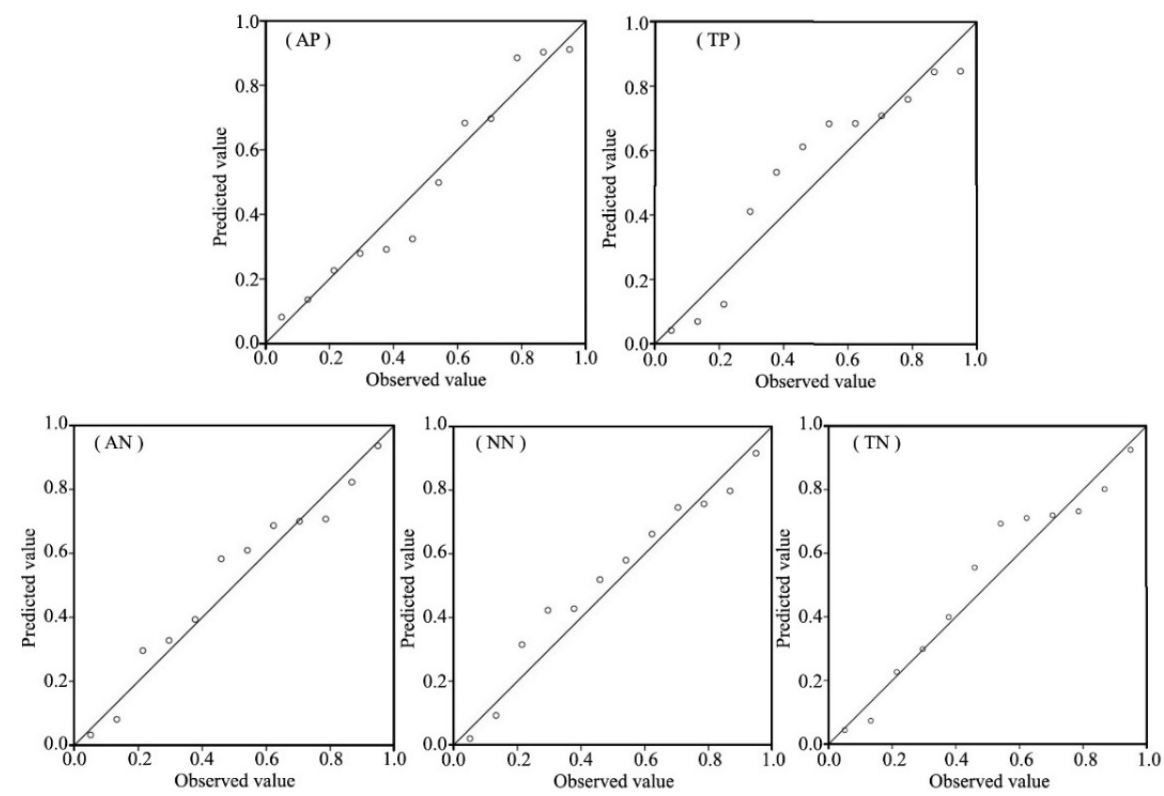

Figure 6. Standardized residual P-P plot.

The relationships between the slope runoff rate and available Phosphorus and total Phosphorus loss rate at different thaw depths are displayed in Figure 7 and Table 4 . The linear regression equation $y=a x+b(a, b$ are constants) is satisfied between the slope runoff rate and the available Phosphorus and total Phosphorus loss rate at all thaw depths (Table 4). However, when the thaw depth is $2 \mathrm{~cm}$, the coefficient of regression equation $\mathrm{R}^{2}$ of runoff rate and available Phosphorus and total Phosphorus is less than 0.5, which is a poor fit. Under the other treatments, the fit is better, and the available Phosphorus and total Phosphorus loss rate increase with the increasing runoff rate, and the rate of increase can be expressed by the regression coefficient $a$. With an increase in the runoff rate, the loss rate of available Phosphorus and total Phosphorus increased fastest when the thaw depth was $4 \mathrm{~cm}$.
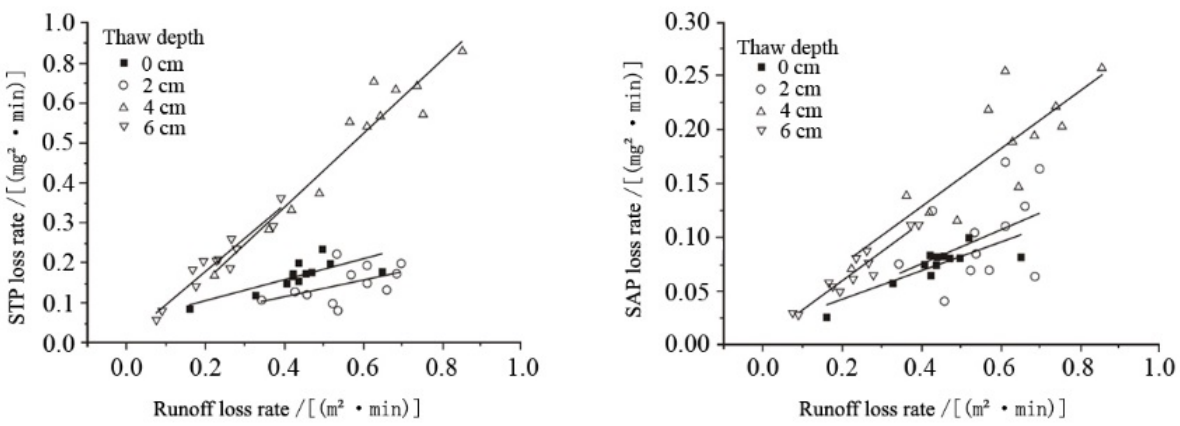

Figure 7. Relationship between runoff rate and Phosphorus loss at different thaw depth. 
Table 4. Regression relationship between the runoff rate and Phosphorus loss at different thaw depths.

\begin{tabular}{ccccc}
\hline \multirow{2}{*}{ Thaw Depth/cm } & \multicolumn{2}{c}{ Total Phosphorus } & \multicolumn{2}{c}{ Available Phosphorus } \\
\cline { 2 - 5 } & Regression Equation & $\mathbf{R}^{\mathbf{2}}$ & Regression Equation & $\mathbf{R}^{\mathbf{2}}$ \\
\hline 0 & $y=0.2589 x+0.0537$ & 0.55 & $y=0.1325 x+0.0161$ & 0.84 \\
2 & $y=0.2148 x+0.0284$ & 0.20 & $y=0.1601 x+0.0113$ & 0.43 \\
4 & $y=0.9199 x-0.0312$ & 0.91 & $y=0.2699 x+0.0207$ & 0.83 \\
6 & $y=0.8352 x+0.01$ & 0.91 & $y=0.2692 x+0.0063$ & 0.96 \\
\hline
\end{tabular}

\subsection{Effect of Thawing Depth on Nitrogen and Phosphorus Loss}

Runoff and rainfall are considered to be important drivers of Nitrogen transport in surface runoff and during leaching. The $\mathrm{AN}$ and $\mathrm{NN}$ and TN loss rate proportions of the total runoff rate for the different thawing depths are shown in Figure 8. The results show that the AN loss rate was the highest for the $4 \mathrm{~cm}$ thaw depth. It rose rapidly at the beginning of the runoff process and continued to increase as time progressed. The AN loss rate at $2 \mathrm{~cm}$ thawing depth first decreased, then rose slowly, and peaked at $35 \mathrm{~min}$. After it had reached its peak, it slowly decreased. However, there was no obvious fluctuation when the thawing depth was 0 and $6 \mathrm{~cm}$. The NN loss rate showed two obvious peak values at 15 and $45 \mathrm{~min}$ when the thawing depth was $0 \mathrm{~cm}$. However, the peak value appeared at $35 \mathrm{~min}$ when the thawing depth was $2 \mathrm{~cm}$. The rate of NN loss did not fluctuate significantly during the whole rainfall period, and it only increased slowly as the runoff time increased when the thawing depth was 4 and $6 \mathrm{~cm}$. The TN loss rate increased as the runoff time increased, and the peak value appeared at $35 \mathrm{~min}$ when the thawing depth was 0,2 , and $4 \mathrm{~cm}$. There was no obvious fluctuation when the thawing depth was $6 \mathrm{~cm}$.
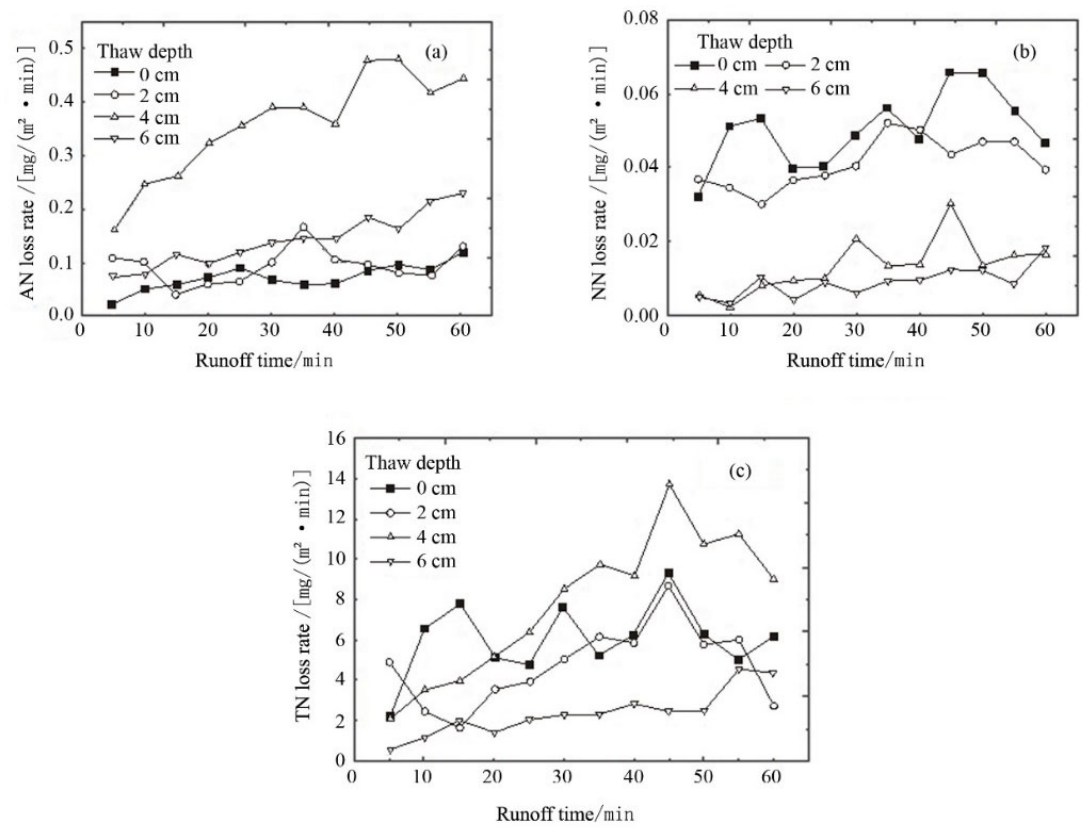

Figure 8. (a-c) Total Nitrogen (TN), ammonium Nitrogen (AN), and nitrate Nitrogen (NN) loss rate components of the total runoff rate at the different thawing depths.

The total amount of Nitrogen loss in runoff for the different thawing depths is shown in Table 5. The AN component of TN loss was the largest when the thawing depth was $6 \mathrm{~cm}$ and smallest at $0 \mathrm{~cm}$. The NN component of TN loss was the largest when the thawing depth was $2 \mathrm{~cm}$ and smallest at $4 \mathrm{~cm}$. These results indicated that the deeper the thawed soil layer, the higher the AN release rate and the lower the $\mathrm{NN}$ release rate in runoff. The 
total Nitrogen loss rate was the highest when the thawing depth was $4 \mathrm{~cm}$, and it increased by $23 \%, 39 \%$, and $70 \%$ when the thawing depth was 0,2 , and $6 \mathrm{~cm}$, respectively.

Table 5. Nitrogen loss in runoff of the different thawing depths.

\begin{tabular}{ccccccc}
\hline Thaw Depth & Runoff & \multicolumn{3}{c}{ Total Loss (mg) } & \multicolumn{2}{c}{ Proportion of TN (\%) } \\
\hline /cm & / $\mathbf{m m}$ & TN & AN & NN & AN & NN \\
\hline 0 & 24.41 & 542.12 & 6.57 & 4.55 & 1.21 & 0.84 \\
2 & 32.84 & 425.76 & 8.46 & 3.75 & 1.99 & 0.88 \\
4 & 33.35 & 702.47 & 32.10 & 1.23 & 4.57 & 0.18 \\
6 & 12.95 & 213.20 & 12.81 & 0.83 & 6.01 & 0.39 \\
\hline
\end{tabular}

The change of available Phosphorus and total Phosphorus loss rate at different thawed depths is shown in Figure 9. When the thaw depth is $0 \mathrm{~cm}$, the available Phosphorus loss rate increases with the increase in runoff time, reaching a peak at 30 min and then slowly decreases and stabilizes. When the thaw depth is $2 \mathrm{~cm}$, the available Phosphorus loss rate fluctuates greatly and has four distinct peaks in the runoff at 10,20,40, and $55 \mathrm{~min}$. With a thaw depth of $4 \mathrm{~cm}$, the available Phosphorus loss rate fluctuates greatly and has three distinct peaks in the runoff at 10,25, and $40 \mathrm{~min}$. With a thaw depth of $6 \mathrm{~cm}$, the available Phosphorus loss rate increases slowly with the increase in runoff duration, decreases slightly at $50 \mathrm{~min}$, and then stabilizes.
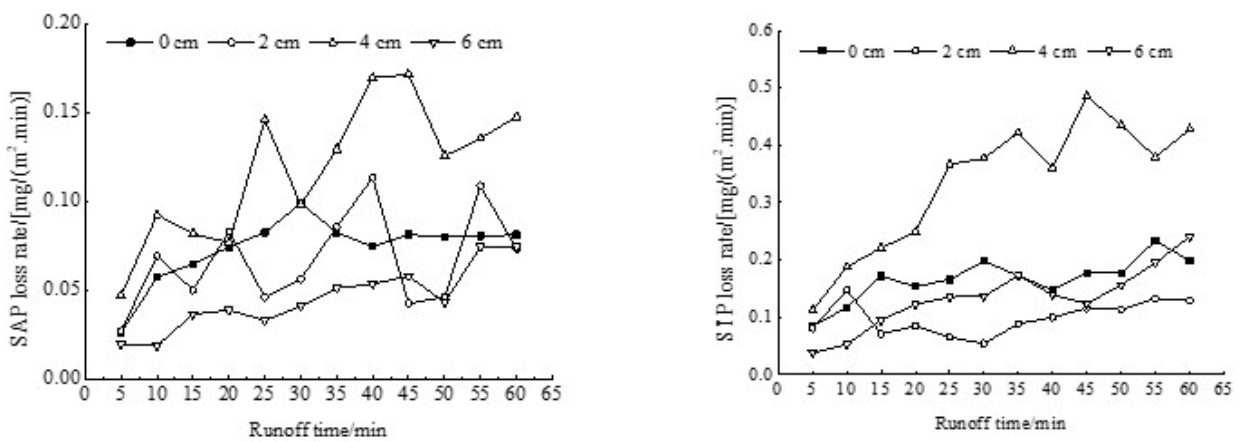

Figure 9. Variation characteristics of Phosphorus loss rate in runoff at different thaw depth.

The change of total Phosphorus loss rate occurs as follows: when the thaw depth is $0 \mathrm{~cm}$, it gradually increases with the increase in runoff duration, and there is no obvious fluctuation pattern. When the thaw depth is $2 \mathrm{~cm}$, a peak occurs at $10 \mathrm{~min}$ of runoff, and the rate then decreases slightly and rises slowly after 30 min of runoff. With a thaw depth of $4 \mathrm{~cm}$, the total Phosphorus loss rate increases rapidly with the increase in runoff duration. It then decreases at $40 \mathrm{~min}$ and reaches a peak at $45 \mathrm{~min}$. When the thaw depth is $6 \mathrm{~cm}$, the rate increases slowly with the increase in runoff duration, and there is no obvious pattern of fluctuation.

Table 6 lists the total available Phosphorus and total Phosphorus loss under different thaw depths. The total available Phosphorus and total Phosphorus loss showed significant differences $(p<0.05)$ under different thaw depths. At a depth range of $0-6 \mathrm{~cm}$, the total loss of total Phosphorus was 14.95, 8.85, 30.17, and $12.04 \mathrm{mg}$, respectively. The order of total Phosphorus loss was: $4 \mathrm{~cm}>0 \mathrm{~cm}>6 \mathrm{~cm}>2 \mathrm{~cm}$. The total available Phosphorus loss was $6.62,6.01,10.65$, and $4.07 \mathrm{mg}$, respectively, which accounted for $44.28 \%, 67.87 \%, 35.30 \%$, and $33.75 \%$ of the total Phosphorus loss. The order of total available Phosphorus loss was: $4 \mathrm{~cm}>2 \mathrm{~cm}>0 \mathrm{~cm}>6 \mathrm{~cm}$. When the thaw depth was 2 and $6 \mathrm{~cm}$, the amount of available Phosphorus loss to the total Phosphorus loss was the largest, and the proportion was the smallest. 
Table 6. Total Phosphorus loss at different thaw depths.

\begin{tabular}{ccccc}
\hline Thaw Depth & The Runoff & \multicolumn{2}{c}{ Loss Amount (mg) } & $\begin{array}{c}\text { The Proportion of Available Phosphorus } \\
\text { to Total Phosphorus (\%) }\end{array}$ \\
\hline $\mathbf{c m}$ & $\mathbf{m m}$ & Total Phosphorus & Available Phosphorus & Available Phosphorus \\
\hline 0 & 24.41 & 14.95 & 6.62 & 44.28 \\
2 & 32.84 & 8.85 & 6.01 & 67.87 \\
4 & 33.35 & 30.17 & 10.65 & 35.30 \\
6 & 12.95 & 12.04 & 4.07 & 33.75 \\
\hline
\end{tabular}

The available Phosphorus and total Phosphorus loss rate increased with the increase in runoff rate, and the total Phosphorus loss decreased in the order: $4 \mathrm{~cm}>0 \mathrm{~cm}>6 \mathrm{~cm}>$ $2 \mathrm{~cm}$. The order of total available Phosphorus loss was: $4 \mathrm{~cm}>2 \mathrm{~cm}>0 \mathrm{~cm}>6 \mathrm{~cm}$. Total Phosphorus and available Phosphorus both first increased and then decreased with the increase in runoff energy.

\subsection{Effect of Runoff Power and Runoff Energy on Nitrogen and Phosphorus Loss}

Runoff energy refers to the work performed by a thin layer of water in a unit area per unit time, and it reflects the ability of a thin layer of water on a slope to ablate and transport the soil. The runoff power reflects the comprehensive response of runoff erosion and underlying surface conditions during rainfall. Therefore, in order to better analyze the response relationship between the underlying surface and the loss of Nitrogen in runoff under hydraulic erosion conditions, the runoff energy and runoff power of the slope were calculated and analyzed to identify the relationships among runoff energy and runoff power and Nitrogen loss in runoff.

Runoff energy and runoff power of the different thawing depths are shown in Table 7. The runoff energy and runoff power orders for the different thawing depths were both $2 \mathrm{~cm}>4 \mathrm{~cm}>0 \mathrm{~cm}>6 \mathrm{~cm}$.

Table 7. Runoff energy and runoff power of the different thawing depths.

\begin{tabular}{ccc}
\hline Thaw Depth/cm & Runoff Energy/J $\cdot \mathbf{m}^{-\mathbf{2}}$ & Runoff Power $/ \mathbf{L}^{\mathbf{4}} \cdot \mathbf{s}^{\mathbf{- 1}} \cdot \mathbf{m}^{-\mathbf{2}}$ \\
\hline 0 & 0.247 & 0.239 \\
2 & 0.485 & 0.438 \\
4 & 0.346 & 0.381 \\
6 & 0.212 & 0.143 \\
\hline
\end{tabular}

The relationships between runoff energy, runoff power, and Nitrogen loss for the different thawing depths are shown in Figure 10. The TN and AN loss increased at first but then decreased as the runoff energy rose, which satisfied the quadratic function relationship. However, the relationship between NN loss and runoff energy was not significant $(p>0.05)$, which indicated that the effect of runoff energy on nitrate loss was not clear. Runoff power has a significant effect on TN loss, and the relationship between them can be described by a quadratic function. The TN loss increased at first and then decreased as the runoff power rose, but the relationship between runoff power and $\mathrm{AN}$ and $\mathrm{NN}$ was not significant $(p>0.05)$. 

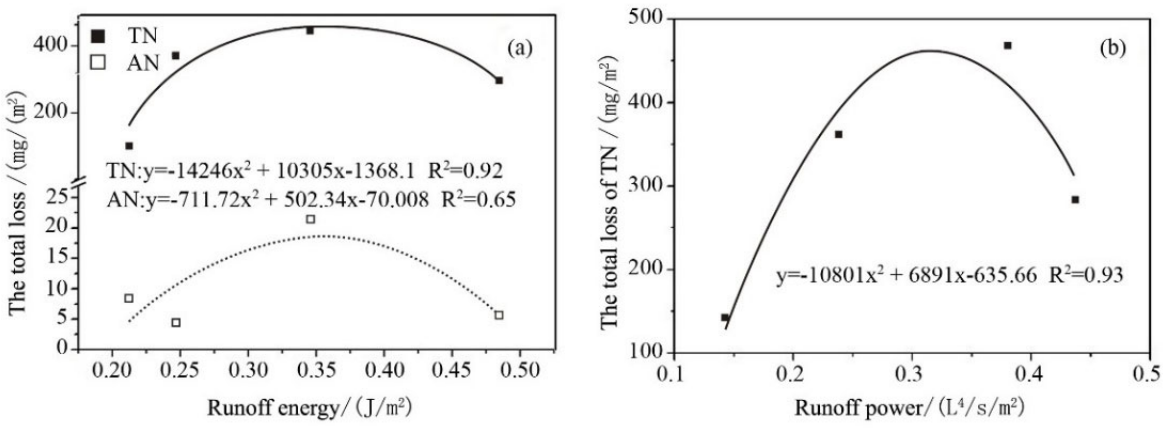

Figure 10. $(\mathbf{a}, \mathbf{b})$ Relationships between runoff energy, runoff power, and Nitrogen loss of the different thawing depths.

The relationship between runoff energy and total Phosphorus and available Phosphorus loss on the slopes with different thaw depths is illustrated in Figure 11. Total Phosphorus and available Phosphorus both increased at first and then decreased with an increase in runoff energy. Regression analysis shows that they have a quadratic function relationship, and the fitting coefficients $\mathrm{R}^{2}$ were 0.93 and 0.99 , respectively. There is a critical value between the amount of Phosphorus loss and the average runoff energy. When the runoff energy exceeds this critical value, the Phosphorus loss decreases as the runoff energy increases.
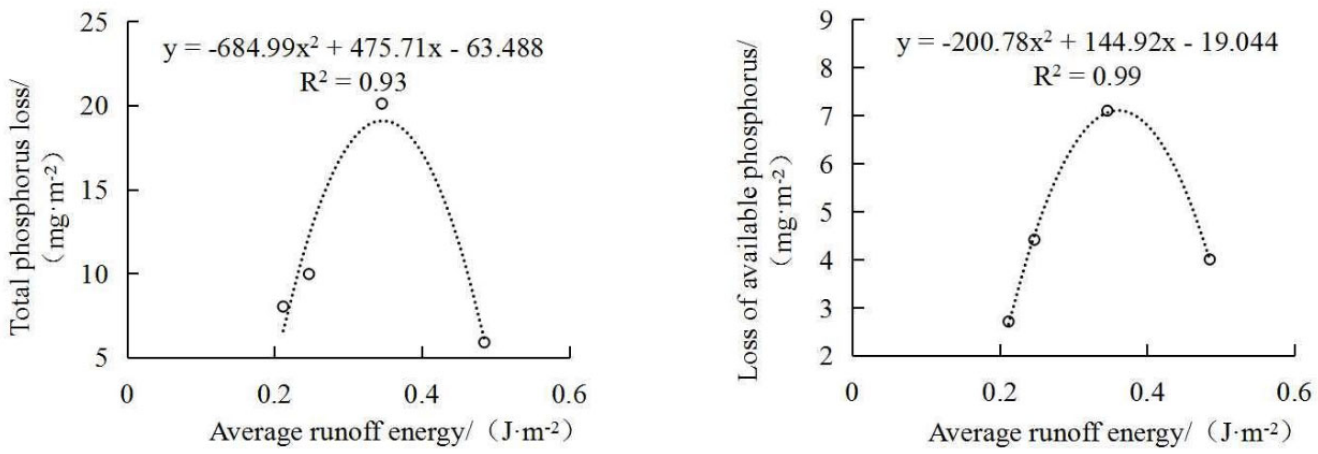

Figure 11. Relationship between runoff energy and Phosphorus loss at different thaw depth.

The relationship between runoff power and total Phosphorus and available Phosphorus loss at different thaw depths is shown in Figure 12. The relationship between runoff power and both total Phosphorus and available Phosphorus satisfies the quadratic function $y=a x^{2}+b x+c\left(a, b\right.$, and $c$ are constants), and the fitting coefficients $\mathrm{R}^{2}$ are 0.38 and 0.70 , respectively. The fitting relationship between runoff power and total Phosphorus is not significant $(p>0.05)$, which shows that there is no clear effect of runoff power on Phosphorus loss. Runoff power has a significant effect on the loss of available Phosphorus. As the runoff power increases, the amount of available Phosphorus loss at first increases and then decreases. 

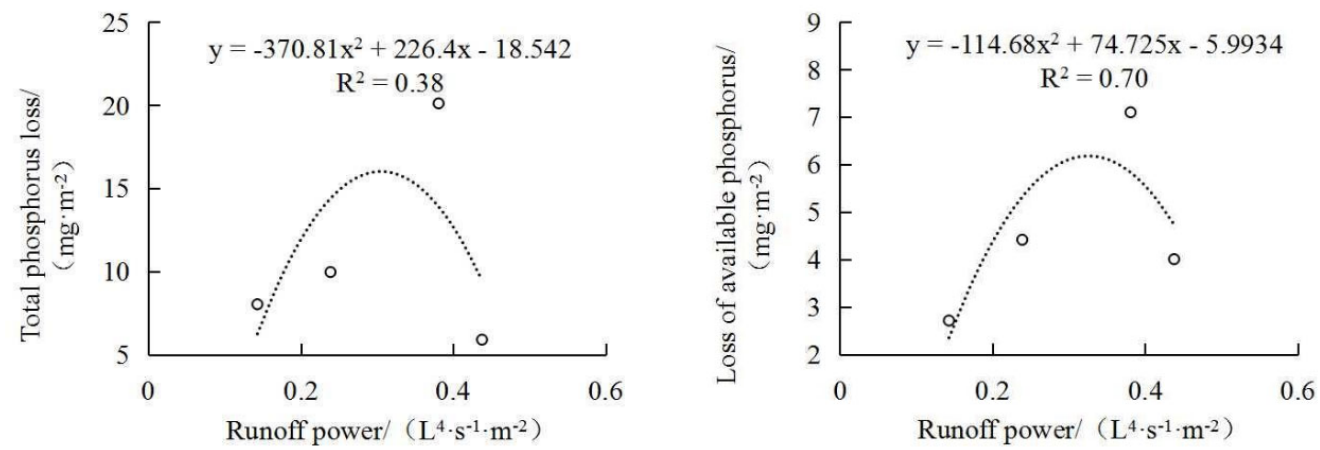

Figure 12. Relationship between runoff power and Phosphorus loss at different thaw depth.

\section{Discussion}

\subsection{Nitrogen and Phosphorus Loss Response to Overland Runoff}

Rainfall has a considerable impact on runoff and determines the initial runoff time [34-37]. Under freeze-thaw conditions, thawing depth also influences the initial runoff time. The runoff time rose as the thaw depth increased. These results are in agreement with Fan et al. [8], who reported that the smaller the soil thaw depth, the shorter the runoff time. This is because the existence of permafrost reduces the infiltration capacity of the soil. Furthermore, the closer the permafrost is to the soil surface, the shorter the time required for the water to concentrate on the slope, and the less time needed for runoff generation. The appearance of water flow is an important point during the rill erosion process, and the appearance of water in the drop pits shows the beginning of rill erosion [38]. This difference was related to the development of rill erosion on the slope. The earlier the rill erosion occurred, the greater the runoff loss on the slope [8]. This is inconsistent with the results of this paper because the soil properties and slopes selected in the experiment were different compared to those of the previous paper. The large thawing depth meant that it took a long time for the rain to infiltrate the frozen soil layer after rainfall had begun, which leads to a late runoff occurrence time. Furthermore, the soil water content in the topsoil gradually increased until it reached saturation.

Seasonal freezing and thawing, rainfall intensity, and slope play important roles in runoff generation, soil loss, and nutrient movement [39]. The freeze-thaw action of the soil changes, for example, the structure of the soil aggregates, water stability, porosity, bulk density, water content, and the specific surface area, resulting in runoff changing [7,25-29]. When the rainfall intensity is low, most of the initial rainwater can infiltrate into the soil, and the runoff yield is small and the sediment carrying capacity of the runoff is also very weak [40].

\subsection{Nitrogen and Phosphorus Loss Changes Resulting from Thawing Depth and Runoff Dynamic}

The freeze-thaw cycle has a significant effect on the ammonia Nitrogen and nitrate Nitrogen proportions in inorganic Nitrogen. The inorganic Nitrogen was mainly composed of NN at the beginning of freezing and thawing. However, as the number of freezethaw cycles increases, the NN proportion gradually decreases, and the AN proportion increases [41]. In this paper, as the thawing depth increased, the AN proportion in runoff rose, whereas the NN proportion did not show any obvious pattern. This is because the soil thawing process promotes the release of AN from organic and inorganic colloids in the soil, which results in an AN content increase in the runoff. In addition, the freezing and thawing effect has a significant effect on microbial activity. The soil microbes die, and the cells dissolve, which releases Nitrogen during the freeze-thaw process. Furthermore, the formation of a frozen soil layer is conducive to the nitrification process and promotes the formation of NN. This explains why the NN loss was the largest when the thawing depth was $0 \mathrm{~cm}$.

Phosphorus is easily adsorbed by soil particles. Before the eroded soil is removed from the soil particles, Phosphorus can be quickly removed from the soil regardless of the rainfall 
intensity. Nutrient loss on sloping land occurs due to the interaction between rainfall runoff and sloping soil [42]. In this paper, the available Phosphorus and total Phosphorus loss rate increased with the increase in runoff rate. The rainfall has a significant impact on runoff and nutrient loss [43,44]. Previous research [45] has found that the frozen layer and thawed layer generate a large amount of runoff. Slaughter and Yamazaki came to a similar conclusion [46,47].

Runoff energy were larger when the thawing depths were 2 and $4 \mathrm{~cm}$. Runoff energy mainly affected the TN and AN loss in runoff, whereas runoff power mainly affected TN loss in runoff. There was a critical value for the effects of erosion energy on total Nitrogen loss. Under the experimental conditions used in this paper, when the runoff energy and runoff power were too high or too low, there was a reduction in the total Nitrogen loss. However, the thawing process meant that the surface soil was dissolved whereas the lower part remained frozen. Furthermore, there is an impermeable layer at the interface between the thawed and frozen soil, which makes the soil erosion process different from a totally thawed slope. Therefore, the mechanism underlying the relationship between hydraulic erosion and Nitrogen loss on slopes is complicated. The relationship between hydraulic erosion and Nitrogen loss cannot be accurately measured using hydrodynamics and energy or be described by a single quantitative description. These relationships require further study in the future. Ahuja et al. [48] found that rainfall kinetic energy increases the migration of chemicals from soil solutions to runoff by increasing the mixing and diffusion of Phosphorus elements. The increase in rainfall intensity leads to the increase in rainfall kinetic energy, the enhancement of raindrop detachment ability, and the reduction of runoff time, which may accelerate soil Phosphorus into the surface runoff and increase the initial total Phosphorus loss concentration [43].

\section{Conclusions}

Seasonal freeze-thaw erosion is a form of soil erosion caused by the topographical characteristics and climatic factors of the hilly and gully loess regions. Seasonal freeze-thaw can damage the soil pores and cause its bulk density to change. The loss of nitrogen and phosphorus is quite different under different thawing stages on the Loess Plateau. Therefore, it is necessary to choose the appropriate time for scientific and reasonable fertilization according to the change of temperature to avoid the loss of nitrogen and phosphorus and other fertilizers. At the same time, the results provide an effective theoretical basis for preventing and controlling the loss of nitrogen and phosphorus in different thawing stages for the loess slope. This paper draws the following conclusions based on an indoor simulated rainfall test:

- The runoff rate increases under different thaw depths in the order: $4 \mathrm{~cm}$ (runoff rate) > $2 \mathrm{~cm}>0 \mathrm{~cm}>6 \mathrm{~cm}$. With the increase in runoff time, the slope infiltration rate had a decreasing trend. The loss rate of available and total Phosphorus increased with the increase in runoff rate. The rate of increase was fastest when the thawing depth was $4 \mathrm{~cm}$.

- The relationships between runoff rate and Nitrogen loss, Phosphorus loss rate can be explained by linear regression equations, and the loss rate increased as the runoff rate rose for all thawing depths. Within the $0-6 \mathrm{~cm}$ thawing depths, the order of total Phosphorus loss was: $4 \mathrm{~cm}$ (total Phosphorus loss) $>0 \mathrm{~cm}>6 \mathrm{~cm}>2 \mathrm{~cm}$, and available Phosphorus loss was: $4 \mathrm{~cm}$ (available Phosphorus loss) $>2 \mathrm{~cm}>0 \mathrm{~cm}>6 \mathrm{~cm}$. At the shallower thawing depths, the AN loss represented a smaller proportion of the TN loss compared to NN loss. However, there was a gradual rise in the AN proportion in the total amount of inorganic Nitrogen as the thawing depth increased.

- Total Phosphorus was the available Phosphorus with a quadratic function relationship with runoff energy and runoff power. Runoff energy mainly affected the TN and AN loss in runoff, whereas runoff power mainly affected TN loss in runoff. 
Author Contributions: F.W., Z.L. and Y.C. conceived the main idea of the paper. P.L., B.W. and H.Z. designed and performed the experiment. F.W. wrote the manuscript and all authors contributed in improving the paper. All authors have read and agreed to the published version of the manuscript.

Funding: This research was supported by the National Natural Science Foundation of China (U2040208, 42007069), the Science and Technology Program of Yulin (Grant NO. 2019-144), The foundation of State Key Laboratory of Eco-hydraulics in Northwest Arid Region Xi'an University of Technology(2020KFKT-2), and the Science and Technology Project of Department of Transport of Shaanxi Province (Grant NO. 2015-11K).

Institutional Review Board Statement: Not applicable.

Informed Consent Statement: Not applicable.

Data Availability Statement: Not applicable.

Acknowledgments: We thank the reviewers for their useful comments and suggestions.

Conflicts of Interest: The authors state that they have no known competing financial interests or personal relationships that could affect the work described in this article.

\section{References}

1. Han, L.; Wan, Z.M.; Sun, H.Y. Research progress on the effects of freezing and thawing on soil physical, chemical and biological properties. Chin. J. Soil Sci. 2018, 49, 736-742, (In Chinese with English abstract).

2. Shi, P.; Zhang, Y.; Zhang, Y.; Yu, Y.; Li, P.; Li, Z.B.; Xiao, L.; Xu, G.C.; Zhu, T.T. Land-use types and slope topography affect the soil labile carbon fractions in the Loess hilly-gully area of Shaanxi, China. Arch. Agron. Soil Sci. 2020, 66, 638-650. [CrossRef]

3. Zhang, Y.; Li, P.; Liu, X.J.; Zhao, B.H. Effects of farmland conversion on the stoichiometry of carbon, nitrogen, and phosphorus in soil aggregates on the Loess Plateau of China. Geoderma 2019, 351, 188-196. [CrossRef]

4. Ban, Y.Y.; Lei, T.W.; Chen, C.; Yin, Z.; Qian, D.F. Meltwater erosion process of frozen soil as affected by thawed depth under concentrated flow in high altitude and cold regions. Earth Surf. Processes Landf. 2017, 42, 2139-2146. [CrossRef]

5. Cheng, Y.; Li, P.; Xu, G.; Li, Z.; Wang, T. Effect of soil erodibility on nitrogen and phosphorus loss under condition of freeze-thaw. Trans. Chin. Soc. Agric. Eng. 2017, 33, 141-149, (In Chinese with English abstract).

6. Sharratt, B.S.; Lindstrom, M.J.; Benoit, G.R.; Young, R.A.; Wilts, A. Runoff and soil erosion during spring thaw in the northern U.S. Corn Belt. J. Soil Water Conserv. 2000, 55, 487-494.

7. Wang, T.; Li, P.; Ren, Z.P.; Xu, G.C.; Li, Z.B.; Yang, Y.Y.; Tang, S.S.; Yao, J.W. Effects of freeze-thaw on soil erosion processes and sediment selectivity under simulated rainfall. J. Arid Land 2017, 9, 234-243. [CrossRef]

8. Fan, H.M.; Zhang, R.F.; Wu, M.; Zhou, L.L. Study on Sloping Land Rainfall Erosion Affected by Thaw Depth of Near-surface Meadow Soil. J. Soil Water Conserv. 2010, 24, 28-31, (In Chinese with English abstract).

9. Wang, T.; Li, P.; Hou, J.M.; Li, Z.B.; Ren, Z.P.; Cheng, S.D.; Xu, G.C.; Su, Y.Y.; Wang, F.C. Response of the Meltwater Erosion to Runoff Energy Consumption on Loessal Slopes. Water 2018, 10, 1522. [CrossRef]

10. Ala, M.; Liu, Y.; Wang, A.Z.; Niu, C.Y. Characteristics of soil freeze-thaw cycles and their effects on water enrichment in the rhizosphere. Geoderma Int. J. Soil Sci. 2016, 264, 132-139.

11. Wang, T.; Li, P.; Li, Z.B.; Hou, J.M.; Xiao, L.; Ren, Z.P.; Xu, G.C.; Yu, K.X.; Su, Y.Y. The effects of freeze-thaw process on soil water migration in dam and slope farmland on the Loess Plateau, China. Sci. Total Environ. 2019, 666, 721-730. [CrossRef] [PubMed]

12. Wang, T.; Li, P.; Liu, Y.; Hou, J.M.; Li, Z.B.; Ren, Z.P.; Cheng, S.D.; Zhao, J.H.; Hinkelmann, R. Experimental investigation of freeze-thaw meltwater compound erosion and runoff energy consumption on loessal slopes. Catena 2020, 185, 104310. [CrossRef]

13. Xiao, L.; Zhang, Y.; Li, P.; Xu, G.C.; Shi, P.; Zhang, Y. Effects of freeze-thaw cycles on aggregate-associated organic carbon and glomalin-related soil protein in natural-succession grassland and Chinese pine forest on the Loess Plateau. Geoderma 2019, 334, 1-8. [CrossRef]

14. $\mathrm{Xu}, \mathrm{H}$.; Wang, F.F.; Li, T.; Wu, X. A review of freezing-thawing cycle effects on key processes of soil nitrogen cycling and the underlying mechanisms. Acta Ecol. Sin. 2020, 40, 3168-3182, (In Chinese with English abstract).

15. Fan, H.M.; Huang, D.H.; Zhou, L.; Zhou, L.L.; Jia, Y. Effects of freeze-thaw cycles on phosphorus adsorption and desorption in the black soil of northeastern China. Acta Agric. Scand. 2014, 64, 24-32. [CrossRef]

16. Schmidt, S.; Lipson, D. Microbial growth under the snow: Implications for nutrient and allelochemical availability in temperate soils. Plant Soil 2004, 259, 1-7. [CrossRef]

17. Hinman, W. Effects of freezing and thawing on some chemical properties of three soils. Can. J. Soil Sci. 1970, 50, 179-182. [CrossRef]

18. Dagesse, D.F. Freezing-induced bulk soil volume changes. Can. J. Soil Sci. 2010, 90, 389-401. [CrossRef]

19. Wang, Z.W.; Yang, J.Y. Freezing and thawing of soil carbon impact. China Sci. Technol. Inf. 2009, 4, 24-27, (In Chinese with English abstract)

20. Li, N.; Tang, J.; Zhang, N.; Yu, S.L. Soil Organic Carbon and Its Relationship with Enzyme during Freezing-Thawing-Cycles in Paddy Soil. Environ. Sci. Technol. 2015, 38, 1-6, (In Chinese with English abstract). 
21. Shi, P.; Qin, Y.L.; Liu, Q.; Zhu, T.T.; Li, Z.B.; Li, P.; Ren, Z.P.; Liu, Y.; Wang, F.C. Soil respiration and response of carbon source changes to vegetation restoration in the Loess Plateau, China. Sci. Total Environ. 2020, 707, 135507. [CrossRef] [PubMed]

22. Yu, X.F.; Zou, Y.C.; Jiang, M.; Lu, X.G.; Wang, G.P. Response of soil constituents to freeze-thaw cycles in wetland soil solution. Soil Biol. Biochem. 2011, 43, 1308-1320. [CrossRef]

23. Qian, D.; Fan, H.M.; Zhou, L.L.; Wu, M.; Guo, P. Effects of freezing-thawing on phosphorus adsorption and desorption characteristics in brown earth. J. Soil Water Conserv. 2012, 26, 279-283, (In Chinese with English abstract).

24. Li, L.; Meng, Q.Y. Reviews of phosphorus transport and transformation in soil under freezing and thawing actions. Ecol. Environ. Sci. 2013, 22, 1074-1078, (In Chinese with English abstract).

25. Oztas, T.; Favetorbay, F. Effect of freezing and thawing processes on soil aggregate stability. Catena 2003, 52, 1-8. [CrossRef]

26. Chamberlain, E.J.; Gow, A.J. Effect of freezing and thawing on the permeability and structure of soils. Eng. Geol. 1979, 13, 73-92. [CrossRef]

27. Edwards, L.M. The effect of alternate freezing and thawing on aggregate stability and aggregate size distribution of some Prince Edward Island soils. J. Soil Sci. 1991, 42, 193-204. [CrossRef]

28. Zhao, B.H.; Li, Z.B.; Li, P.; Xiao, L.; Chang, E.H.; Zhang, Y.; Gao, B. Effects of ecological construction on the transformation of different water types on Loess Plateau, China. Ecol. Eng. 2020, 144, 105642. [CrossRef]

29. Lehrsch, G.A. Freeze-thaw cycles increase near-surface aggregate stability. Soil Sci. 1998, 163, 63-70. [CrossRef]

30. Pawluk, S. Freeze-thaw effects on granular structure reorganization for soil materials of varying texture and moisture content. Can. J. Soil Sci. 1988, 68, 485-494. [CrossRef]

31. Wang, T.; Li, P.; Li, Z.B.; Xu, G.C.; Cheng, S.D.; Ren, Z.P.; Li, X.T.; Wang, F.C.; Yang, Y.Y.; Dong, S.S. A Kind of Intelligent Multifunctional Artificially-Simulated Rainfall System. China Patent 201710524790.7, 27 July 2018.

32. Boardman, J.; Favis-Mortlock, D.; Foster, I. A 13-year record of erosion on badland sites in the Karoo, South Africa. Earth Surf. Processes Landf. 2015, 40, 1964-1981. [CrossRef]

33. Ren, Z.P.; Ma, Y.Y.; Wang, Y.S.; Xie, M.Y.; Li, P. Runoff changes and attribution analysis in tributaries of different geomorphic regions in Wuding River basin. Acta Ecol. Sin. 2019, 39, 4309-4318.

34. Hua, W.X.; Fan, H.M.; Xu, X.Q.; Jia, Y.F.; Liu, Y.J.; Tan, J.; Zhang, N. Observation on the Spring Snowmelt Erosion of Sloping Farmland in Northeast China. J. Soil Water Conserv. 2017, 31, 92-96.

35. Han, D.D.; Deng, J.C.; Gu, C.J.; Mu, X.M.; Gao, P.; Gao, J.J. Effect of shrub-grass vegetation coverage and slope gradient on runoff and sediment yield under simulated rainfall. Int. J. Sediment Res. 2021, 36, 34-42. [CrossRef]

36. Wu, L.; Peng, M.L.; Qiao, S.S.; Ma, X.Y. Effects of rainfall intensity and slope gradient on runoff and sediment yield characteristics of bare loess soil. Environ. Sci. Pollut. Res. 2018, 25, 1-8. [CrossRef]

37. Yong, L.K.; Law, P.L.; Taib, S.; Ngu, J.; Mah, D.; Law, S. A study on topography versus sediment yield under simulated rainfall. IOP Conf. Ser. Mater. Sci. Eng. 2021, 1101, 012019. [CrossRef]

38. Hao, H.X.; Guo, Z.L.; Wang, X.Z.; Zhan, H.G.; Ma, R.M.; Li, Z.X.; Juan, J. Rill erosion process on red soil slope under interaction of rainfall and scouring flow. Trans. Chin. Soc. Agric. Eng. 2017, 33, 134-140, (In Chinese with English abstract).

39. Guo, Z.L.; Ma, M.J.; Cai, C.F.; Wu, Y.W. Combined effects of simulated rainfall and overland flow on sediment and solute transport in hillslope erosion. J. Soil Sediments 2018, 18, 1120-1132. [CrossRef]

40. Foster, I.D.L.; Chapman, A.S.; Hodgkinson, R.M.; Jones, A.R.; Lees, J.A.; Turner, S.E.; Scott, M. Changing suspended sediment and particulate phosphorus loads and pathways in underdrained lowland agricultural catchments; Herefordshire and Worcestershire, U.K. Hydrobiologia 2003, 494, 1-3. [CrossRef]

41. Kreyling, J.; Schumann, R.; Weigel, R. Soils from cold and snowy temperate deciduous forests release more nitrogen and phosphorus after soil freeze-thaw cycles than soils from warmer, snow-poor conditions. Biogeosciences 2020, 134, 5194. [CrossRef]

42. Yao, L.U.; Hu, W.L.; Lei, B.K.; Duan, Z.Y.; Liu, H.B.; Zhai, L.M. Location monitoring of nitrogen and phosphorus loss in red soil surface runoff of farmland in Yunnan Province. J. Agro-Environ. Sci. 2012, 31, 1544-1553.

43. Chen, L.; Liu, D.F.; Song, L.X.; Cui, Y.J.; Zhang, G. Characteristics of Nutrient Loss by Runoff in Sloping Arable Land of Yellowbrown Under Different Rainfall Intensities. Environ. Sci. 2013, 34, 2151-2158.

44. Ran, Q.H.; Su, D.Y.; Li, P.; He, Z.G. Experimental study of the impact of rainfall characteristics on runoff generation and soil erosion. J. Hydrol. 2012, 424, 99-111. [CrossRef]

45. Wischmeier, W.H.; Smith, D.D. Predicting rainfall erosion losses-a guide to conservation planning. In Agriculture Handbook; Department of Agriculture, Science and Education Administration: Washington, DC, USA, 1978.

46. Slaughter, C.W.; Hilgert, J.W.; Culp, E.H. Summer Streamflow and Sediment Yield from Discontinuous-Permafrost Headwaters Catchments. In Proceedings of the 4th International Conference on Permafrost, Fairbanks, AK, USA, 18-22 July 1983.

47. Yamazaki, Y.; Kubota, J.; Ohata, T.; Vuglinsky, V.; Mizuyama, T. Seasonal changes in runoff characteristics on a permafrost watershed in the southern mountainous region of eastern Siberia. Hydrol. Processes 2010, 20, 453-467. [CrossRef]

48. Ahuja, L.R.; Sharpley, A.N.; Lehman, O.R. Effect of Soil Slope and Rainfall Characteristics on Phosphorus in Runoff. J. Environ. Qual. 1982, 11, 9-13. [CrossRef] 